\title{
Differential Regulation of Two Glucose Transporters in Adipose Cells from Diabetic and Insulin-treated Diabetic Rats
}

\author{
Barbara B. Kahn, " Maureen J. Charron," Harvey F. Lodish, ${ }^{\dagger 5}$ Samuel W. Cushman," and Jeffrey S. Flier \\ *The Charles A. Dana Research Institute and Harvard-Thorndike Laboratory of Beth Israel Hospital, Department of Medicine, Beth \\ Israel Hospital and Harvard Medical School, Boston, Massachusetts 02215; ${ }^{\ddagger}$ Whitehead Institute for Biomedical Research, Cambridge, \\ Massachusetts 02142; ¿Department of Biology, Massachusetts Institute of Technology, Cambridge, Massachusetts 02139; and \\ "Experimental Diabetes, Metabolism and Nutrition Section, Molecular, Cellular and Nutritional Endocrinology Branch, National \\ Institute of Diabetes and Digestive and Kidney Diseases, National Institutes of Health, Bethesda, Maryland 20892
}

\begin{abstract}
At least two genetically distinct glucose transporters (GTs) coexist in adipose cells, one cloned from human hepatoma cells and rat brain (HepG2/brain) and another from rat skeletal muscle, heart, and adipose cells (adipose cell/muscle). Here we demonstrate differential regulation of these two GTs in adipose cells of diabetic and insulin-treated diabetic rats and compare changes in the expression of each GT with marked alterations in insulin-stimulated glucose transport activity. Adipose cell/muscle GTs detected by immunoblotting with the monoclonal antiserum $1 F 8$ (James, D. E., R. Brown, J. Navarro, and P. F. Pilch. 1988. Nature (Lond.). 333:183-185), which reacts with the protein product of the newly cloned adipose cell/muscle GT cDNA, decrease $87 \%$ with diabetes and increase to 8.5-fold diabetic levels with insulin treatment. These changes concur qualitatively with previous detection of GTs by cytochalasin B binding and with insulin-stimulated 3-O-methylglucose transport. Northern blotting reveals that the adipose/muscle GT mRNA decreases $50 \%$ with diabetes and increases to 6.8-fold control (13-fold diabetic) levels with insulin treatment. In contrast, GTs detected with antisera to the carboxyl terminus of the HepG2 GT or to the human erythrocyte GT show no significant change with diabetes or insulin treatment. The HepG2/brain GT mRNA is unchanged with diabetes and increases threefold with insulin treatment. These results suggest that $(a)$ altered expression of the adipose cell/ muscle GT forms the molecular basis for the dysregulated glucose transport response to insulin characteristic of diabetes, (b) the expression of two types of GTs in rat adipose cells is regulated independently, and (c) alterations in mRNA levels are only part of the mechanism for in vivo regulation of the expression of either GT species.
\end{abstract}

\section{Introduction}

Glucose transport in response to insulin is markedly impaired in adipose cells in insulin-resistant states such as diabetes (1-3), and this may play a key role in the altered glucose homeostasis characteristic of diabetes. A major determinant of cellular glucose transport activity is the number of glucose

Address correspondence to Dr. Barbara B. Kahn, Diabetes Unit, Beth Israel Hospital, 330 Brookline Avenue, Boston, MA 02215.

Received for publication 27 December 1988 and in revised form 18 April 1989.

J. Clin. Invest.

(c) The American Society for Clinical Investigation, Inc.

0021-9738/89/08/0404/08 $\$ 2.00$

Volume 84, August 1989, 404-411 transporters present in the cell; this number is dramatically altered in disease states (1-3). Efforts to understand the regulation of glucose transporter number have been complicated by the recent demonstration that glucose transport is not mediated by a single protein species (4-9). ${ }^{1}$ In fact, multiple glucose transporter and glucose transporter-like genes exist whose translation products are distinct due to differences in amino acid sequence (4-10) or in posttranslational modifications (11, 12). It is now critical to determine how each glucose transporter is regulated and to what extent each contributes to the changes in glucose homeostasis seen in disease states.

The first glucose transporter to be cloned was obtained by screening human hepatoma (HepG2) cell (4) and rat brain (5) cDNA libraries with a polyclonal antibody directed against the human erythrocyte-facilitated diffusion glucose transporter. The resulting sequences are $98 \%$ homologous at the protein level and are presumed to represent the same glucose transporter. In both humans and rats this glucose transporter (HepG2/brain) is present in multiple non-insulin-sensitive and insulin-sensitive tissues including adipose cells (13). ${ }^{1}$ The extent to which this transporter modulates constitutive and/or insulin-stimulated glucose transport has not yet been determined. However, mRNA levels for this transporter correlate with changes in glucose transport activity and glucose transporter number in cultured cells transfected with oncogenes $(14,15)$ or treated with phorbol esters (14). Additionally, alterations in the mRNA levels for this glucose transporter correlate with alterations in the number of glucose transporters in adipose cells from fasted and refed rats (16), a model for insulin-resistant and hyperresponsive glucose transport, respectively. Transfection of this transporter into Chinese hamster ovary cells (17) and cultured 3T3-L1 adipocytes (18) has demonstrated that it participates in the stimulatory effect of insulin on glucose transport and it can be translocated to the plasma membrane in response to insulin.

Very recently a second glucose transporter that is present in adipose cells has been cloned from rat soleus muscle (7), adipose cells, and heart (6). This transporter is expressed predominately in insulin-responsive tissues and shows a greater degree of translocation to the plasma membrane in adipose cells after insulin stimulation than does the HepG2/brain transporter $(6){ }^{1}$ Evidence $(6,19)^{2}$ suggests that it is at least 10 times as abundant in adipose cells and muscle as the HepG2/ brain glucose transporter. Hence, it could account for most of the glucose transport response to insulin in these tissues.

1. Charron, M. J., G. Baldini, and H. F. Lodish, manuscript in preparation.

2. Jones, T., H. C. Haspel, and S. W. Cushman, unpublished observations. 
Whereas other authors have referred to this as the insulin-regulated glucose transporter (6), we will refer to each glucose transporter species according to the tissues from which it was cloned, since other glucose transporters appear to show some insulin responsiveness $(17,18)$.

The adipose cell glucose transport defect in diabetes is one of marked resistance to the acute stimulatory effect of insulin which (as measured by cytochalasin B binding) results from a depletion of cellular glucose transporters $(1,3)$. Chronic insulin therapy not only reverses this resistance but brings about a transient overshoot in insulin-stimulated glucose transport to threefold control levels $(20,21)$ due to increases in both glucose transporter number and intrinsic activity (moles of glucose/glucose transporter per unit time). Cytochalasin B binding, a standard technique for assessing the number of glucose transporters (22), may detect multiple species of glucose transporters in adipose cells $(19,23)$. Therefore, the current study was designed to determine whether diabetes and insulin treatment of diabetes coordinately regulate the two genetically distinct species of glucose transporters identified to date in adipose cells. The relationship among distinct glucose transporter mRNA levels, glucose transporters as assessed by cytochalasin $B$ binding and three anti-glucose transporter antisera, and glucose transport activity in adipose cells was examined. These data help to elucidate the potential functional roles of the HepG2/brain and adipose cell/muscle glucose transporters in the dysregulated glucose transport seen in disease states such as diabetes.

\section{Methods}

Animals and experimental design. Male Sprague-Dawley rats (CD strain; Charles River Breeding Laboratories, Inc., Wilmington, MA) were received at body weights ranging from 140 to $150 \mathrm{~g}$ and maintained with ad lib. feeding (standard National Institutes of Health [NIH] chow) for several days before initiation of the experimental period. Rats were treated with injection of $80-85 \mathrm{mg} / \mathrm{kg}$ i.p. anhydrous streptozotocin and citric acid (Zanosar; The Upjohn Co., Kalamazoo, MI) and one group was infused with subcutaneous insulin as previously described (20). Control rats received no treatment, as sham injections have previously been shown to have no effect on blood glucose concentrations, adipose cell size, or glucose transport activity (20). Blood glucose was measured in whole blood using Chemstrips bG (Bio-Dynamics, Indianapolis, IN) read in an Accuchek bG reflectance meter (Bio-Dynamics).

Preparation of isolated adipose cells and measurement of cell size. Immediately after the animals were killed in the fed state by brief exposure to $\mathrm{CO}_{2}$ followed by decapitation, the whole epididymal fat pads were removed and isolated adipose cells were prepared by the method originally described by Rodbell (24) and subsequently modified by Cushman (25) using crude collagenase (Cooper Biomedical, Malvern, PA). All incubations were carried out in KRB reduced to 10 $\mathrm{mM} \mathrm{HCO}_{3}^{-}$and supplemented with $30 \mathrm{mM}$ Hepes (Sigma Chemical Co., St. Louis, $\mathrm{MO}$ ), $\mathrm{pH} 7.4,37^{\circ} \mathrm{C}$, containing $1 \%$ untreated BSA (BSA powder, fractions V; Reheis Chemical Co., Kankakee, IL). Adipose cell size was determined by the osmic acid fixation, Coulter electronic counter method (Method III; Coulter Electronics Inc., Hialeah, FL) described by Hirsch and Gallian (26) for intact tissue fragments, and modified for isolated cell suspensions by Cushman and Salans (27).

Measurement of adipose cell glucose transport activity and intracellular water space. Isolated adipose cells from a minimum of eight rats for each experimental group were incubated at $37^{\circ} \mathrm{C}$ for $30 \mathrm{~min}$ in the presence of 0 or $7 \mathrm{nM}(1,000 \mu \mathrm{U} / \mathrm{ml})$ insulin (crystalline porcine zinc; courtesy of Dr. Ronald B. Chance, Eli Lilly and Co., Indianapo- lis, IN). $3-O-\left[{ }^{14} \mathrm{C}\right]$ Methylglucose transport was then assessed using a substrate concentration of $0.1 \mathrm{mM}$ by a modification described by Karnieli et al. (28) of the L-arabinose uptake method of Foley et al. (29). The intracellular water space was determined from the steadystate level of cellular 3-O-methylglucose.

$R N A$ isolation. Isolated adipose cells were prepared as described above and immediately frozen in liquid nitrogen. They were stored at $-70^{\circ} \mathrm{C}$ for $1-14 \mathrm{~d}$ before RNA extraction using the guanadinium thiocyanate- $\mathrm{CsCl}$ technique (30).

Northern gels. RNA was electrophoresed on $1.2 \%$ formaldehyde agarose gels (31), blotted and fixed onto nylon filters, and then hybridized with a cRNA probe for the glucose transporter and a cDNA probe for actin. For the HepG2 glucose transporter cRNA probe, the HepG2 glucose transporter cDNA obtained from Dr. Mike Mueckler (Washington University, St. Louis, MO) (4) was subcloned into the Bam HI site of the pGEM plasmid (Promega Biotech, Madison, WI) and the antisense RNA was synthesized using T7 RNA polymerase (Stratagene, San Diego, CA $)$ and $\left[{ }^{32} \mathrm{P}\right] \mathrm{UTP}(800 \mathrm{Ci} / \mathrm{mmol}$, sp act $)$ as described by the manufacturer. The labeled RNA was separated from unincorporated UTP using phenol/chloroform extraction and elutip columns (Schleicher \& Schuell, Inc., Keene, NH). Hybridization to the cRNA probe $\left(10^{6} \mathrm{cpm} / \mathrm{ml}\right)$ was carried out at $65^{\circ} \mathrm{C}$ in a hybridization solution composed of $50 \%$ formamide, $5 \times$ standard saline citrate (SSC; SSC is $0.15 \mathrm{M}$ sodium chloride and $0.015 \mathrm{M}$ sodium citrate, $\mathrm{pH} 7.0$ ), $1 \times \mathrm{PE}$ (PE is $50 \mathrm{mM}$ Tris, pH 7.5, $0.1 \%$ sodium pyrophosphate, $1 \%$ SDS, $0.2 \%$ polyvinylpyrolidone, $0.2 \%$ Ficoll, $5 \%$ EDTA, $1 \%$ BSA), and 150 $\mu \mathrm{g} / \mathrm{ml}$ denatured salmon sperm DNA. Filters were washed twice for 15 min in $2 \times \mathrm{SSC}, 0.1 \%$ SDS at $65^{\circ} \mathrm{C}$ and twice in $0.1 \times \mathrm{SSC}, 0.1 \%$ SDS at $65^{\circ} \mathrm{C}$.

For the rat muscle glucose transporter cRNA probe the entire 2.49-kb Eco RI fragment of the rat muscle glucose transporter cDNA (7) was subcloned into the Bluescript KS vector (Stratagene) and linearized with Sal I, and the antisense RNA was synthesized as above. Hybridizations were carried out in $50 \%$ formamide, $5 \times$ SSC, $5 \times$ Denhardt's solution ( $1 \times$ Denhardt's solution is $0.02 \%$ polyvinylpyrolidone, $0.02 \%$ Ficoll, $0.02 \%$ BSA), $50 \mathrm{mM}$ phosphate buffer (pH 7.0), $1 \%$ SDS, $100 \mu \mathrm{g} / \mathrm{ml}$ poly(A), $5 \mathrm{mM}$ EDTA at $60^{\circ} \mathrm{C}$ for $16-20 \mathrm{~h}$. The probe was included at $1-2 \times 10^{6} \mathrm{cpm} / \mathrm{ml}$. Filters were washed in $0.1 \times \mathrm{SSC}$, $0.1 \%$ SDS at $65^{\circ} \mathrm{C}$. All filters were then exposed to either Kodak XAR-5 or SB film (Eastman Kodak Co., Rochester, NY) at $-70^{\circ} \mathrm{C}$ for varying time periods (intensifying screen, Cronex Lightening Plus; DuPont Instruments, Wilmington, DE).

The cDNA for beta actin (32) was obtained from Dr. Barret Rollins (Dana Farber Cancer Institute, Boston, MA) and labeled with [ $\left.{ }^{32} \mathrm{P}\right]-$ dCTP by random priming $(33,34)$. Hybridization was carried out at $42^{\circ} \mathrm{C}$ in a solution composed of $50 \%$ formamide, $5 \times$ SSPE (SSPE is 0.9 $\mathrm{M} \mathrm{NaCl}, 5 \mathrm{mM}$ EDTA, and $50 \mathrm{mM} \mathrm{NaH}_{2} \mathrm{PO}_{4}, \mathrm{pH} \mathrm{7.4),0.2 \%} \mathrm{SDS,}$ $0.1 \%$ each of BSA, polyvinylpyrolidine, and Ficoll, and denatured, sheared salmon sperm DNA $(200 \mu \mathrm{g} / \mathrm{ml})$. The probe was included at $10^{6} \mathrm{cpm} / \mathrm{ml}$. Blots were washed three times for $10 \mathrm{~min}$ each in $1.0 \times$ SSPE and $0.1 \%$ SDS at $24^{\circ} \mathrm{C}$, and then three times for $30 \mathrm{~min}$ each in $0.1 \times$ SSPE and $0.1 \%$ SDS at $50-55^{\circ} \mathrm{C}$. The abundance of specific glucose transporter or actin message was quantitated using a scanning densitometer (GS 300; Hoefer Scientific Instruments, San Francisco, CA, or 2202 Ultrascan; LKB Instruments, Inc., Gaithersburg, MD). The areas under the curves were calculated using the GS 350 computer program (Hoefer Scientific Instruments) or 2220 Integrator (LKB Instruments, Inc.).

Preparation of adipose cell subcellular membrane fractions. Subcellular membrane fractions were prepared from a minimum of eight control, 7-d diabetic, or 7-d diabetic/7-d insulin-treated rats. These time points were chosen because previous time-course studies showed maximal alterations in insulin-stimulated glucose transport and significant changes in glucose transporter number at these times $(1,20)$. Isolated adipose cells were incubated at $37^{\circ} \mathrm{C}$ for $30 \mathrm{~min}$ in the presence of 0 or $700 \mathrm{nM}$ insulin, and samples were taken for determination of cell number and 3-O-methylglucose transport. Plasma, high density microsomal, and low density microsomal membrane fractions were 
prepared from the remaining cells by differential centrifugation as previously described (35). Membrane protein was determined by the Coomassie brilliant blue method (protein assay; Bio-Rad Laboratories, Richmond, CA) described by Bradford (36) and modified by Simpson and Sonne (37) using crystalline BSA (Sigma Chemical Co.) as the standard.

Immunoblotting. Adipose cell subcellular membranes prepared as described above were subjected to 7.5 or $10 \%$ SDS-PAGE (38) and electrophoretically transferred to nitrocellulose filters. Identical membranes were used for detection of glucose transporters using three different antisera: A, a polyclonal rabbit antiserum prepared against a synthetic peptide consisting of the $16 \mathrm{COOH}$-terminal amino acids of the HepG2 and rat brain glucose transporter sequence (courtesy of Dr. Bernard Thorens, Whitehead Institute, Cambridge, MA); B, a polyclonal rabbit antiserum prepared against the purified human erythrocyte glucose transporter (courtesy of Dr. David Sogin and Dr. Peter Hinkle, Cornell University, Ithaca, NY) $(39,40)$; and C, a monoclonal antiserum, 1F8, specific for the rat adipose cell/muscle glucose transporter (courtesy of Dr. David James, Washington University, St. Louis, MO) $(6,41)$. Antisera $A$ and $C$ were used at $10 \mu \mathrm{g} / \mathrm{ml}$ and antiserum $B$ at 3.3 $\mu \mathrm{g} / \mathrm{ml}$. Filters were blocked with $5 \%$ nonfat dry milk, washed, and incubated with ${ }^{125} \mathrm{I}$-protein A (New England Nuclear, Boston, MA) after exposure to antisera $A$ and $B$ and with sheep anti-mouse ${ }^{125} I$ $\mathrm{F}\left(\mathrm{ab}^{\prime}\right)_{2}$ fragment (Amersham Corp., Arlington Heights, IL) after exposure to antiserum $C$. Dried filters were autoradiographed using XAR-5 film (Eastman Kodak Co.) and intensifying screens at $-70^{\circ} \mathrm{C}$. Densitometry was performed as described above.

Calculations and statistical analyses. Calculations of 3-O-methylglucose transport and adipose cell size were carried out on the Dartmouth time sharing system computer facilities. Statistical analyses were performed on the Beth Israel Hospital analyzer system using analysis of variance and the Newman-Keuls test. For densitometry data a one sample comparison test was used since these results are evaluated as a percent of control due to the arbitrary nature of OD units. Differences were accepted as significant at the $P \leq 0.05$ level.

\section{Results}

General characteristics of rats and their tissues. Table I shows the effects on blood glucose of $7 \mathrm{~d}$ of diabetes and of 7 subsequent $\mathrm{d}$ of insulin infusion. Mean blood glucose in diabetic rats is $>22.2 \mathrm{mM}$, and insulin treatment restores blood glucose to slightly below normal. With diabetes, adipose cell size is reduced $63 \%$ and intracellular water, a reflection of intracellular protein, is reduced $41 \%$ (Table I). $7 \mathrm{~d}$ of insulin treatment is associated with an increase in cell size although it remains $42 \%$ smaller than control, whereas intracellular water increases to $62 \%$ greater than control. These data are similar to those previously described $(1,20)$. Total RNA/adipose cell does not change with diabetes, but increases to 2.4-fold control levels with $7 \mathrm{~d}$ of insulin treatment.

Glucose transport activity in adipose cells. The effects of $7 \mathrm{~d}$ of diabetes and of 7 subsequent $d$ of insulin treatment on 3-O-methylglucose transport in isolated rat adipose cells are illustrated in Fig. 1. Basal glucose transport activity is not significantly changed with diabetes or insulin treatment although it increases slightly with insulin treatment. In contrast, maximally insulin-stimulated activity decreases $\sim 70 \%$ from control levels with diabetes and is not only restored but increased to $\sim 300 \%$ of control levels with $7 \mathrm{~d}$ of insulin treatment. These results confirm our previous observations (20) which included a more detailed assessment of changes in glucose transport activity with sequential periods of diabetes and insulin treatment ranging from 1 to $35 \mathrm{~d}$.
Table I. Characteristics of Control, 7-d Diabetic and 7-d Diabetic/7-d Insulin-treated Rats

\begin{tabular}{cccc}
\hline & Control & 7-d diabetic & $\begin{array}{c}\text { 7-d diabetic/ } \\
7-\mathrm{d} \text { insulin }\end{array}$ \\
\hline $\begin{array}{c}\text { Blood glucose, } \\
\text { postprandial } \\
(m M)\end{array}$ & $8.0 \pm 0.2$ & $>22.2^{* *}$ & $6.6 \pm 0.5$ \\
$\begin{array}{c}\text { Adipose cell size } \\
(\mu \mathrm{g} \text { lipid/cell })\end{array}$ & $0.201 \pm 0.023$ & $0.075 \pm 0.007^{*}$ & $0.117 \pm 0.005^{*}$ \\
$\begin{array}{c}\text { Adipose cell } \\
\text { intracellular } \\
\text { water }(\mathrm{pl} / \mathrm{cell})\end{array}$ & $2.12 \pm 0.23$ & $1.26 \pm 0.23^{*}$ & $3.44 \pm 0.21^{*}$ \\
$\begin{array}{c}\text { RNA/adipose } \\
\text { cell }(\mathrm{pg} / \mathrm{cell})\end{array}$ & $5.00 \pm 0.57$ & $5.33 \pm 0.86$ & $11.80 \pm 0.92^{*}$
\end{tabular}

Rats were made diabetic and treated with insulin as described in Methods. Blood glucose was measured on all rats when killed. Adipose cell size and intracellular water were determined on pooled cells from 8-22 rats in each group in each of three experiments described in Fig. 1. Results of cell size and intracellular water are means \pm SEM of individual means from duplicate (for cell size) or quadruplicate (for intracellular water) samples in the three separate experiments. * Difference from control at $P \leq 0.05$.

${ }^{\ddagger}$ Maximum value measured by the reflectance meter used to determine blood glucose $=22.2 \mathrm{mM}$.

Glucose transporter and actin $m R N A$ levels in adipose cells. Both the HepG2/brain and adipose cell/muscle glucose transporter antisense RNAs hybridize under stringent conditions with a single 2.7-2.8-kb transcript in adipose cells (Fig. 2). The size of this transcript is unaltered by diabetes or insulin treatment. When Northern blots are loaded with equivalent but arbitrary amounts of RNA per lane (Fig. $2 B$ ) the abundance of the HepG2/brain glucose transporter mRNA is unchanged with diabetes or insulin treatment, whereas the level of adipose cell/muscle glucose transporter decreases with diabetes and increases somewhat above control with insulin treatment. However, RNA/adipose cell (Table I) is markedly increased with insulin treatment of the diabetic rat. Therefore, in Fig. $2 A$ we have loaded quantities of RNA extracted from equivalent numbers of cells in each lane. As we discussed previously (16) this is the most physiologically relevant way of examining the data since our aim is to explain changes in glucose transport activity and glucose transporter number per cell.

Figs. $2 A$ and $3 A$ show that the amount of HepG2/brain glucose transporter mRNA expressed per cell is unchanged with diabetes but increases threefold with insulin treatment. In contrast, the level per cell of the adipose cell/muscle glucose transporter mRNA (Figs. $2 A$ and $3 B$ ) decreases $50 \%$ with diabetes and increases 13 -fold with insulin treatment. The level reaches 6.8-fold that of control cells (Fig. 3 B). Actin mRNA in adipose cells is unchanged with diabetes but increases twofold over control with insulin treatment (Figs. $2 \mathrm{~A}$ and $3 C$ ).

Immunodetection of glucose transporters in adipose cells. The different species of glucose transporters in adipose cell subcellular membrane fractions were assessed by immunoblotting with three different anti-glucose transporter antisera. Each antisera recognizes a protein of $M_{\mathrm{r}} \sim 43-50 \mathrm{kD}$ (Fig. 4), which as previously described is sometimes present as a dou- 


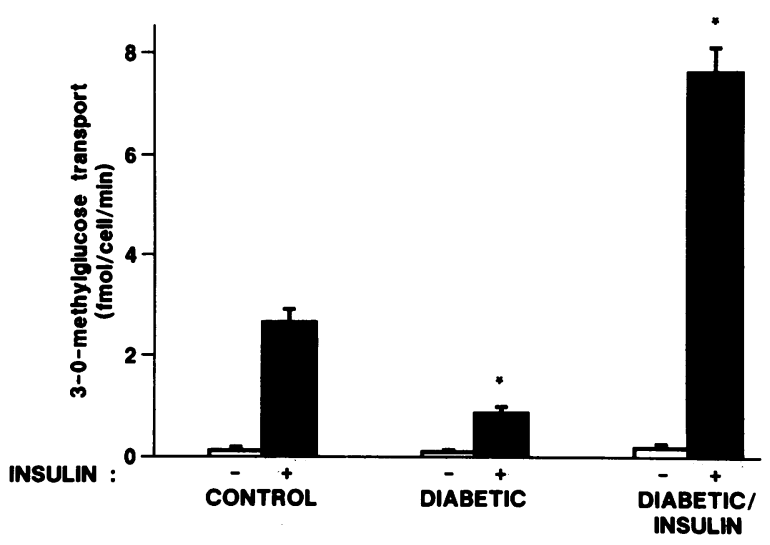

Figure 1. Glucose transport activities in basal and maximally insulinstimulated adipose cells from control, 7-d diabetic, and 7-d diabetic/ $7-d$ insulin-treated rats. Isolated cells were prepared from the epididymal fat pads from 8-22 rats in each group, incubated for 30 min at $37^{\circ} \mathrm{C}$ in the absence or presence of $7 \mathrm{nM}$ insulin, and sampled for measurement of 3-O-methylglucose transport as described in Methods. Results are means \pm SEM of the mean values from at least quadruplicate samples in each of three separate experiments. ${ }^{*}$ Difference from control at $P \leq 0.05$.

blet $(12,41)$. With antisera specific for the HepG2 glucose transporter carboxyl terminus (Fig. $4 A$ ) and the erythrocyte glucose transporter (Fig. $4 \mathrm{~B}$ ) a much fainter, higher molecular weight band is also seen which has previously been reported in adipose cell membranes probed with an antiserum specific for the carboxyl terminus of the HepG2/brain glucose transporter (42). Antiserum 1F8 (Fig. $4 \mathrm{C}$ ) recognizes the protein product of the adipose cell/muscle glucose transporter gene (6).

In plasma membranes from basal adipose cells of diabetic rats, both the antisera against the HepG2 and the erythrocyte glucose transporters (Fig. 4, $A$ and $B$ ) reveal minimal change in immunodetectable glucose transporters (i.e., the amount of signal per milligram of membrane protein) compared with controls; in plasma membranes from insulin-stimulated cells there is a slight decrease of immunodetectable glucose transporters relative to control. There is a slight increase in immunodetectable glucose transporters in the low-density microsomes from adipose cells of diabetic rats, especially in the basal state.

In marked contrast, immunoblotting of the identical membranes from diabetic rat adipose cells with an antiserum to the adipose cell/muscle glucose transporter (Fig. $4 C$ ) shows a marked reduction in the abundance of glucose transporters in both plasma membranes and low density microsomes isolated from both basal and insulin-stimulated cells.

In cells from insulin-treated diabetic rats, whether in the basal or insulin-stimulated state, antisera against the HepG2 (Fig. $4 \mathrm{~A}$ ) and erythrocyte (Fig. $4 \mathrm{~B}$ ) glucose transporter reveal the level of immunodetectable glucose transporters (per milligram of protein) to be slightly decreased in plasma membranes relative to control cells and slightly increased above control in the corresponding low density microsomes. In contrast, the level of the adipose cell/muscle glucose transporter (as assayed by the 1F8 antiserum) is higher in plasma membranes from insulin-treated diabetic rats, whether in the basal or insulinstimulated state, relative to control rats (Fig. $4 C$ ); the level in low density microsomes is slightly decreased.

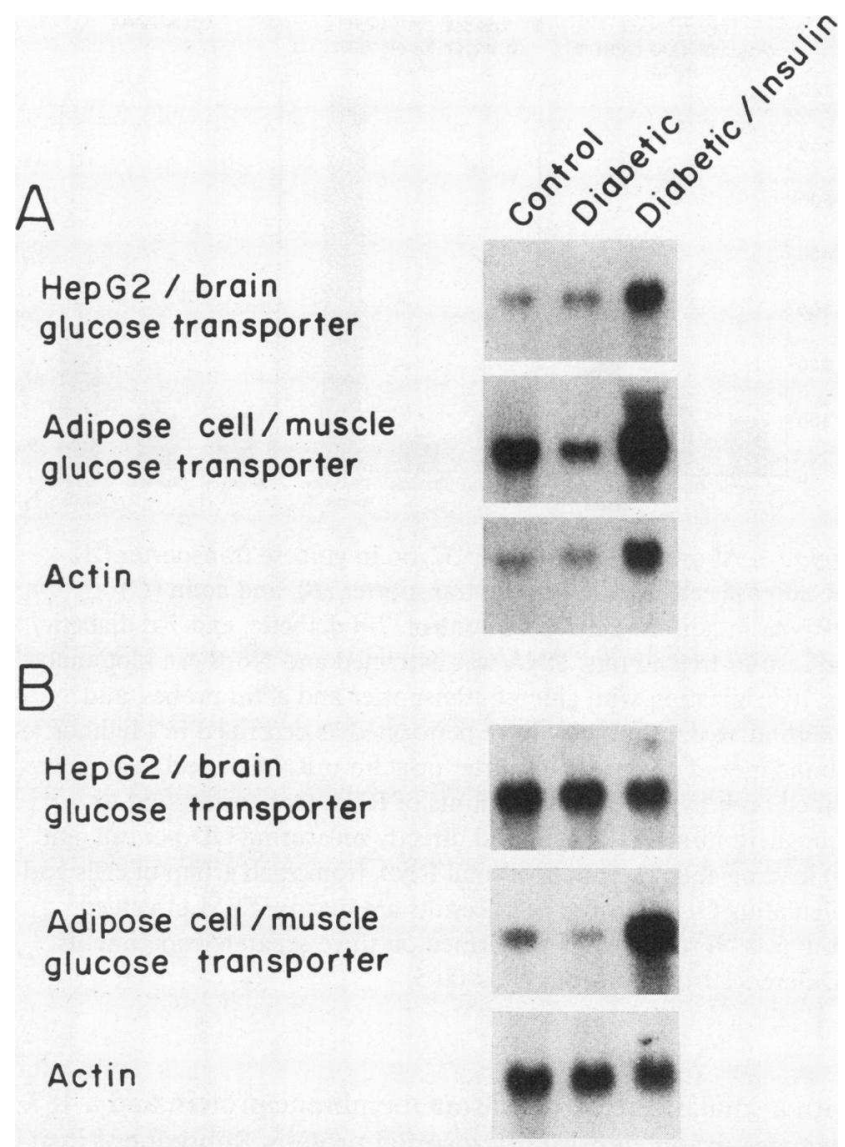

Figure 2. Detection of specific mRNA in adipose cells from control, 7-d diabetic, and 7-d diabetic/7-d insulin-treated rats by Northern gel blot analysis. Isolated cells were prepared and sampled as described in Fig. 1, RNA was extracted, and Northern analysis was performed as described in Methods. $(A)$ Amounts of RNA representing equivalent numbers of cells were loaded. The amounts were determined separately for each set of 8-22 rats based on RNA/cell determined in triplicate. For the HepG2/brain glucose transporter: control, $18 \mu \mathrm{g}$; diabetic, $14 \mu \mathrm{g}$; and diabetic/insulin-treated, $40 \mu \mathrm{g}$; for the adipose cell/muscle glucose transporter and actin: control, $25 \mu \mathrm{g}$; diabetic, 23 $\mu \mathrm{g}$; and diabetic/insulin-treated, $46 \mu \mathrm{g}$. (B) $25 \mu \mathrm{g}$ of RNA were loaded in each lane for the HepG2/brain glucose transporter and actin, and $16 \mu \mathrm{g}$ for the adipose cell/muscle glucose transporter. Blots were hybridized with riboprobes for the glucose transporters and a random primed cDNA probe for actin as described in Methods. Autoradiograms were exposed for 3-11 d for the glucose transporters and $6 \mathrm{~h}$ for actin at $-70^{\circ} \mathrm{C}$. These blots are representative of 5-6 Northern blots performed on three separate experiments.

Previous studies measuring cytochalasin B binding in subcellular membrane fractions from diabetic rats showed a $45 \%$ decrease in the level of glucose transporters in low density microsomes in the basal state compared with control, and a $53 \%$ reduction in the number in the plasma membranes in the insulin-stimulated state (1). In cells from insulin-treated diabetic rats, glucose transporter concentration in the low density microsomes in the basal state, measured by cytochalasin B binding, is equal to control, and in the plasma membranes in the insulin-stimulated state is $\sim 35 \%$ greater than control (20).

The amounts of protein recovered in the membrane preparations used in Fig. 4 are listed in the legend to Fig. 4, and are similar to our previous results $(1,20)$. Diabetes is associated 


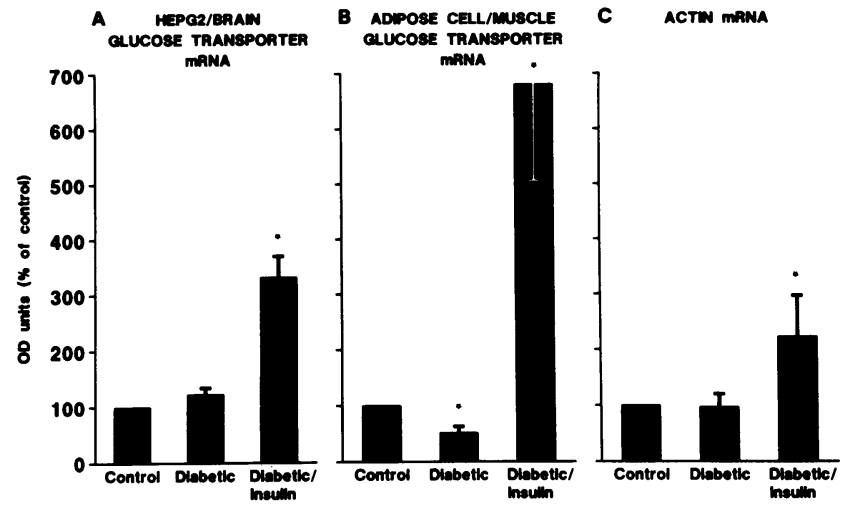

Figure 3. Abundance of the HepG2/brain glucose transporter $(A)$, the adipose cell/muscle glucose transporter $(B)$, and actin $(C)$ mRNAs in adipose cells from control, 7-d diabetic, and 7-d diabetic/ 7-d insulin-treated rats. RNA was extracted and Northern blot analyses, hybridization with glucose transporter and actin probes, and quantitative densitometry were performed as described in Methods. Abundance of glucose transporter or actin mRNA per cell was determined both by $(a)$ loading amounts of RNA that correspond to equivalent numbers of cells and directly measuring OD per cell, and (b) loading equal amounts of total RNA from each group of cells and calculating OD units per cell. Results are means \pm SEM of values from 5-6 Northern blots performed on three separate experiments. *Difference from control at $P \leq 0.05$.

with a small decrease in plasma membrane protein and a $48 \%$ decrease in low density microsomal protein. Subsequent insulin treatment is associated with 57 and $56 \%$ increases in plasma membrane and low density membrane protein, respectively. The increment in plasma membrane protein over control is greater than we previously reported and may result from the slightly larger size of the rats and their adipose cells at the start of the study; hence, with insulin treatment they may recover more rapidly from the catabolic effects of diabetes.

A comparison between the estimated total cellular glucose transporters and levels of mRNA for each of the two glucose transporters is shown in Fig. 5. Because glucose transporters detected with the polyclonal antiserum raised against the partially purified human erythrocyte glucose transporter (Fig. 4 B) closely correspond to those detected with the anti-HepG2 glucose transporter peptide antiserum (Fig. $4 A$ ), we have included only the latter data in the comparisons. The relative abundance of each species of glucose transporter per cell was estimated as previously described (35) by multiplying the OD values for immunoreactive glucose transporters per milligram of membrane protein in the plasma membranes and low density microsomes by the total amount of membrane protein in that fraction, dividing by the number of cells, and summing the values for the two fractions. For comparison, values for total cellular glucose transporters detected by cytochalasin B binding in previous studies $(1,20)$ were also calculated by the same technique. In those studies we demonstrated no significant change in the recoveries or cross-contamination of the membrane fractions with diabetes or insulin treatment. Glucose transporters in high density microsomes are not included in this calculation because they are generally due to contamination from the other two membrane fractions and they make up a relatively small portion of the total cellular glucose transporters (35). In several experiments in which high density mi- crosomal glucose transporters were included in the calculations, the same relative values for total cellular glucose transporters with diabetes and insulin treatment were obtained (data not shown).

With diabetes, the levels of both HepG2/brain glucose transporter mRNA and protein per cell are minimally different from control (Fig. 5). After $7 \mathrm{~d}$ of insulin treatment of diabetic rats, the level of this transporter protein is still unaltered but the amount of mRNA increases approximately threefold. In marked contrast, the level of the adipose cell/ muscle glucose transporter decreases $87 \%$ with diabetes and the level of the corresponding mRNA falls $\sim 50 \%$. With insulin treatment, the level of the adipose cell/muscle glucose transporter increases 8.5-fold from the diabetic levels to slightly above control levels. The level of the corresponding mRNA increases to 6.8-fold that of control and 13-fold that of the diabetic. Both with diabetes and insulin treatment the level of glucose transporters detected by cytochalasin B binding changes in parallel with that detected by the adipose cell/muscle glucose transporter antiserum. Because many assumptions are involved in these calculations (35), these results should be interpreted cautiously and used for comparative purposes only.

\section{Discussion}

At least two genetically distinct glucose transporters are present in rat adipose cells as evidenced by Northern blot analyses and by cDNA cloning $(4-7,13) .{ }^{1}$ Here we show that diabetes and its treatment with insulin differentially regulate the expression of these two glucose transporters in adipose cells. The level of the adipose cell/muscle glucose transporter protein decreases to $13 \%$ of control with diabetes and increases 8.5 fold to slightly above control levels with insulin treatment. In contrast, the level of the HepG2/brain glucose transporter is minimally altered by diabetes or by subsequent insulin treatment. These changes in transporter protein are partially but not fully paralleled by changes in the level of the corresponding transporter mRNA.

To examine the extent to which the HepG2/brain and adipose cell/muscle glucose transporters in adipose cells contribute to the changes in insulin-stimulated glucose transport with diabetes and insulin treatment, we compared the relative rates of insulin-stimulated glucose transport in intact cells with the abundance in the insulin-stimulated state of each of the glucose transporter species in the plasma membrane (Fig. 6). This comparison is made since only those transporters that have been recruited to the plasma membrane mediate glucose transport activity in the intact cell. Strikingly, glucose transport activity and plasma membrane glucose transporters detected by cytochalasin $\mathbf{B}$ binding decrease with diabetes in parallel with transporters detected by the antiserum 1F8 specific for the adipose cell/muscle glucose transporter. In contrast, there is no change in transporters detected by the anti-HepG2 glucose transporter antiserum. With insulin treatment, glucose transport activity and plasma membrane glucose transporters detected by cytochalasin B binding increase in parallel with transporters detected by $1 \mathrm{~F} 8$, whereas glucose transporters detected by the HepG 2 glucose transporter antiserum are again unchanged.

Preliminary data suggest that the adipose cell/muscle glucose transporter, detected by antiserum $1 \mathrm{~F} 8$, is at least 10 


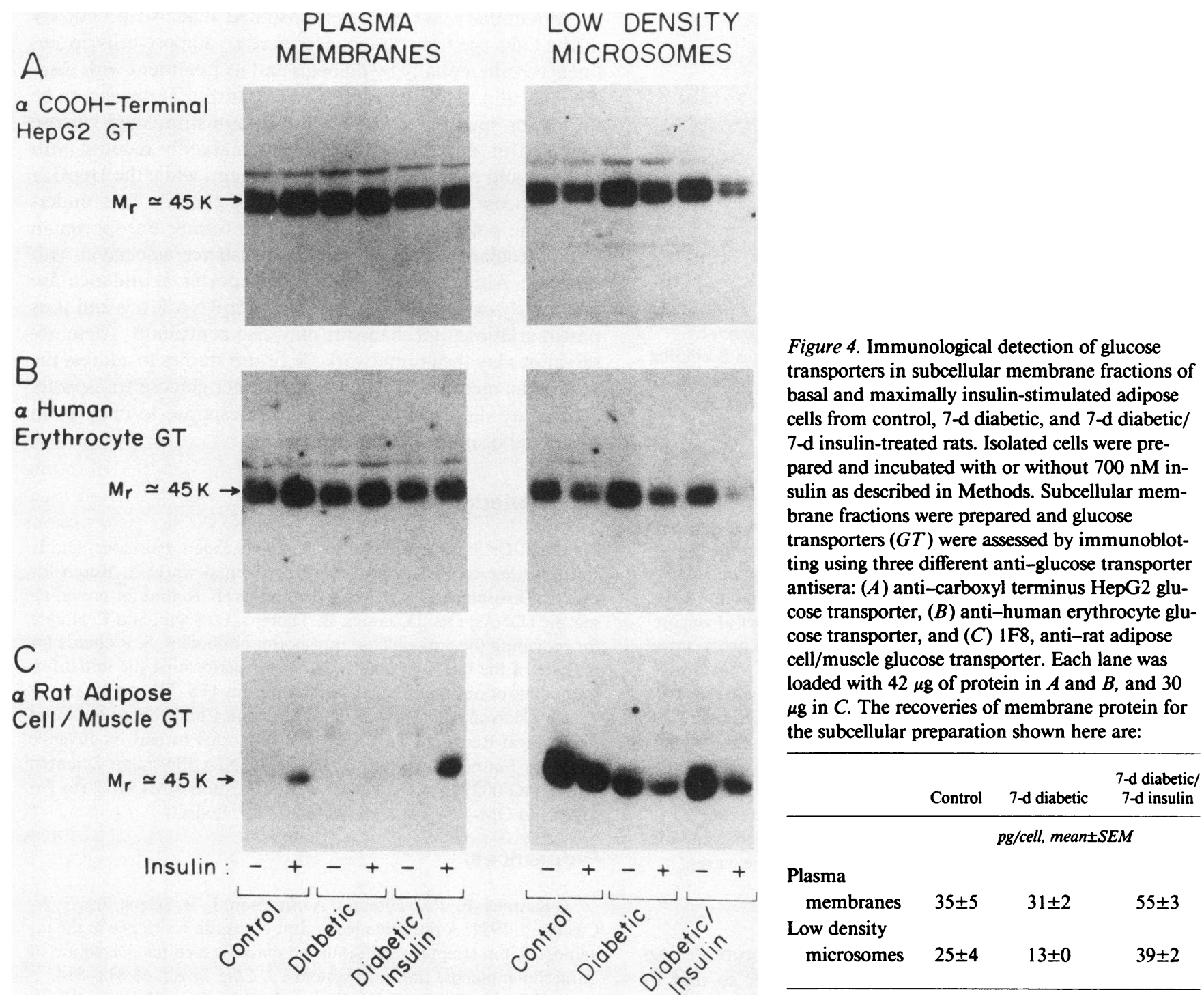

times more abundant in adipose cells than is the HepG2/brain glucose transporter $(6,19){ }^{2}$ Thus, changes in the abundance of the adipose cell/muscle glucose transporter, detected by antiserum 1F8, could account for most of the insulin-resistant glucose transport seen in diabetes and part of the hyperresponsive glucose transport seen with insulin treatment of diabetes. The fact that in insulin-treated diabetic rats insulinstimulated glucose transport activity increases to $286 \%$ of control, while glucose transporters in the plasma membrane detected by 1 F8 increase to only $157 \%$ of control (Fig. 6), is consistent with previous observations that insulin treatment of the diabetic rat is also associated with an increase in glucose transporter intrinsic activity $(20,21)$.

The role of the HepG2/brain glucose transporter in normal and disease states remains to be clarified. This transporter could mediate the relatively low rate of glucose transport seen in the adipose cell in the absence of insulin. We recently showed that changes in the HepG2/brain glucose transporter mRNA correlate with changes in glucose transporter number as measured by cytochalasin B binding in adipose cells from fasted and refed rats (16). This correlation is probably coincidental as the regulation of this glucose transporter mRNA appears to be part of a more generalized phenomenon affecting multiple mRNAs including those for several cytoskeletal and adipose cell-specific proteins. In addition, recent evidence suggests that the HepG2/brain transporter may be a small component of the glucose transporters detected by cytochalasin B binding in adipose cells $(19,23)$. This is supported by our results (Fig. 5) that glucose transporters detected by cytochalasin $B$ binding change in parallel with those detected by an antiserum (1F8) against the adipose cell/muscle glucose transporter.

With both glucose transporters there is a discordance between changes in mRNA and protein levels. Even greater discrepancies have been observed previously with glucokinase whose mRNA increases 50 -fold with refeeding after fasting, while levels of enzyme activity increase only 3-fold (43); similar results have been reported with L-type pyruvate kinase (44). Several explanations are possible for differences between changes in glucose transporter mRNA and protein levels. These include alterations, as a result of the altered metabolic state, in the stability or translatability of the mRNA or in the stability of the protein. Insulin is known to affect the abundance of many mRNAs and proteins in various tissues (45, 


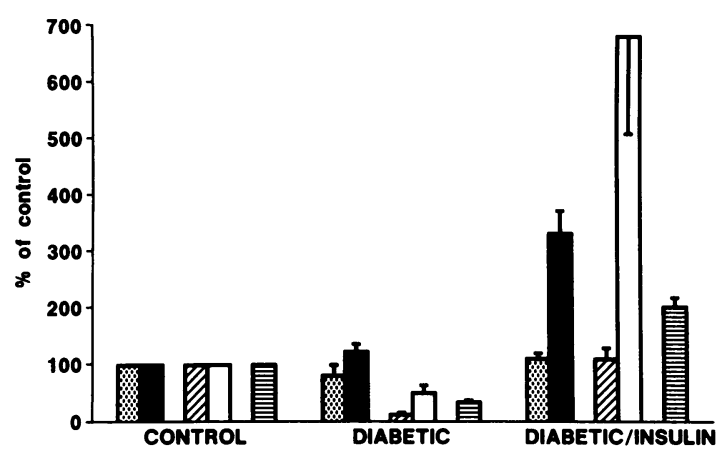

Figure 5. Comparison of the estimated total number of glucose transporters detected by immunoblotting and cytochalasin $\mathrm{B}$ binding and glucose transporter mRNA levels in adipose cells from control, 7-d diabetic, and 7-d diabetic/7-d insulin-treated rats. HepG2/ brain glucose transporters (莐, rat adipose cell/muscle glucose transporters (国), HepG2/brain glucose transporter mRNA levels ( $($ ), and adipose cell/muscle glucose transporter mRNA levels ( $\square$ ). OD values for immunoreactive glucose transporters in plasma membranes and low density microsomes from cells in the basal or insulin-stimulated state determined as described in Fig. 4 were multiplied by the milligrams of protein in the respective membrane fractions and divided by the number of cells. Values for plasma membranes and low density microsomes were summed to estimate a total number of glucose transporters per cell (35). Results are the mean \pm SEM of two to three separate experiments. In each experiment values for the total number in the basal and insulin-stimulated states were calculated separately and averaged. Cytochalasin B binding data for glucose transporter number are derived from measurements published in references 1 and 20 and are calculated in the same way. Glucose transporter mRNA data are from Fig. 3 and are means \pm SEM of OD values from five to six Northern blots from three separate experiments. For each experiment the results in cells from diabetic and diabetic/insulin-treated rats are expressed as a percent of the corresponding control.

46). Conceivably this could include proteins that promote degradation of the HepG2/brain glucose transporter so that its level is unaltered in the insulin-treated diabetic rat in spite of an increase in the level of its mRNA.

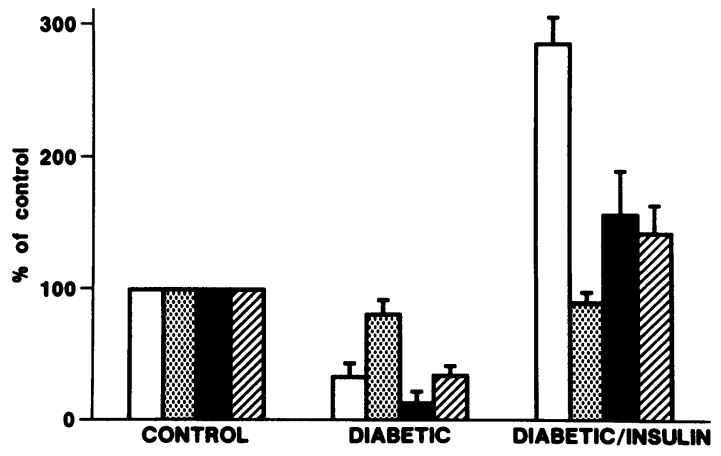

Figure 6. Comparison of insulin-stimulated glucose transport activity ( $\square$ ), the number of HepG2/brain (⿴囗十) and adipose cell/muscle ( $\square$ ) glucose transporters, and glucose transporters detected by cytochalasin B binding ( $(a)$ in plasma membranes from insulin-stimulated adipose cells. Glucose transporter number was calculated as described in Fig. 5 , but for plasma membranes from insulin-stimulated cells only. 3-O-Methylglucose transport results are from Fig. 1. Results are the mean \pm SEM of two to three separate experiments. For each experiment the results in cells from diabetic and diabetic/insulin-treated rats are expressed as a percent of the corresponding control.
In summary, we have demonstrated that two genetically distinct glucose transporters expressed in adipose cells are influenced differentially by diabetes and its treatment with insulin. The adipose cell/muscle glucose transporter appears to be the major species responsible for insulin-stimulated glucose transport in adipose cells. Its level is markedly reduced with diabetes and restored by insulin treatment, while the HepG2/ brain glucose transporter is minimally altered. This underscores the potential importance of the former transporter in the molecular basis of the insulin resistance associated with diabetes. Alterations in glucose transporter abundance are only partly explained by alterations in mRNA levels and thus posttranslational mechanisms may also contribute. These observations lay the groundwork for future studies to address the molecular mechanisms by which distinct glucose transporter species are discordantly regulated in response to changes in hormonal or metabolic states.

\section{Acknowledgments}

We thank Dr. L. Wardzala for his generous expert assistance, Dr. T. Jones for her contribution to the experimental work, A. Rosen for technical assistance, Dr. M. Mueckler and Dr. B. Rollins for providing specific cDNAs, Drs. D. James, B. Thorens, D. Sogin, and P. Hinkle for providing the anti-glucose transporter antibodies, S. Richards for his care of the rats, and Dr. D. James for performing the initial immunoblots of our membranes with antiserum 1F8 (Fig. $4 \mathrm{C}$ ).

Dr. Charron is a fellow of the Jane Coffin Childs Memorial Fund for Medical Research. This work was supported in part by Juvenile Diabetes Foundation grant 187487 and NIA Physician Scientist Award AG-00294 (to Dr. Kahn) and NIH grants AM-28082 (to Dr. Flier) and GM-40916 and HL-41484 (to Dr. Lodish).

\section{References}

1. Karnieli, E., P. J. Hissin, I. A. Simpson, L. B. Salans, and S. W. Cushman. 1981. A possible mechanism of insulin resistance in the rat adipose cell in streptozotocin-induced diabetes mellitus. Depletion of intracellular glucose transport systems. J. Clin. Invest. 68:811-814.

2. Kahn, B. B., and S. W. Cushman. 1985. Subcellular translocation of glucose transporters: role in insulin action and its perturbation in altered metabolic states. Diabetes Metab. Rev. 1:203-227.

3. Garvey, W. T., T. P. Huecksteadt, S. Matthaei, and J. M. Olefsky. 1987. Role of glucose transporters in the cellular insulin resistance of type II non-insulin dependent diabetes mellitus. J. Clin. Invest. 81:1528-1536.

4. Mueckler, M. M., C. Caruso, S. A. Baldwin, M. Panico, I. Blench, H. R. Morris, J. W. Allard, G. E. Lienhard, and H. F. Lodish. 1985. Sequence and structure of a human glucose transporter. Science (Wash. DC). 229:941-945.

5. Birnbaum, M. J., H. C. Haspel, and O. M. Rosen. 1986. Cloning and characterization of cDNA encoding the rat brain glucose-transporter protein. Proc. Natl. Acad. Sci. USA. 83:5784-5788.

6. James, D. E., M. Strube, and M. Mueckler. 1989. Molecular cloning and characterization of an insulin-regulatable glucose transporter. Nature (Lond.). 338:83-87.

7. Charron, M. J., F. C. Brosius III, S. L. Alper, and H. F. Lodish. 1989. A novel glucose transport protein expressed predominately in insulin-responsive tissues. Proc. Natl. Acad. Sci. USA. 86:2535-2539.

8. Fukumoto, H., S. Seino, H. Imura, Y. Seino, R. L. Eddy, Y. Fukushima, M. G. Byers, T. B. Shows, and G. I. Bell. 1988. Sequence, tissue distribution and chromosomal localization of mRNA encoding a human glucose transporter-like protein. Proc. Natl. Acad. Sci. USA. 85:5434-5438.

9. Thorens, B., H. K. Sarkar, H. R. Kaback, and H. F. Lodish. 1988. Cloning and functional expression in bacteria of a novel glucose 
transporter present in liver, kidney and beta pancreatic islet cells. Cell. 55:281-290.

10. Kayano, T., H. Fukumoto, R. L. Eddy, Y. Fan, M. G. Byers, T. B. Shows, and G. I. Bell. 1988. Evidence for a family of human glucose transporter-like proteins. J. Biol. Chem. 263:15245-15248.

11. Simpson, I. A., and S. W. Cushman. 1986. Hormonal regulation of mammalian glucose transport. Annu. Rev. Biochem. 55:10591089.

12. Horuk, R., S. Matthaie, J. M. Olefsky, D. L. Baly, S. W. Cushman, and I. A. Simpson. 1986. Biochemical and functional heterogeneity of rat adipocyte glucose transporters. J. Biol. Chem. 261:18231828.

13. Flier, J. S., M. Mueckler, A. L. McCall, and H. F. Lodish. 1987. Distribution of glucose transporter messenger RNA transcripts in tissues of rat and man. J. Clin. Invest. 79:657-661.

14. Flier, J. S., M. M. Mueckler, P. Usher, and H. F. Lodish. 1987. Elevated levels of glucose transport and transporter messenger RNA are induced by ras or src oncongenes. Science (Wash. DC). 235:14921495.

15. Birnbaum, M. J., H. C. Haspel, and O. M. Rosen. 1987. Transformation of rat fibroblasts by FSV rapidly increases glucose transporter gene transcription. Science (Wash. DC). 235:1495-1498.

16. Kahn, B. B., S. W. Cushman, and J. S. Flier. 1989. Regulation of glucose transporter-specific mRNA levels in rat adipose cells with fasting and refeeding: implications for in vivo control of glucose transporter number. J. Clin. Invest. 83:199-204.

17. Asano, T., Y. Shibasaki, S. Ohno, H. Taira, J. Lin, M. Kasuga, Y. Kanazawa, Y. Akanuma, F. Takaku, and Y. Oka. 1989. Rabbit brain glucose transporter responds to insulin when expressed in insulin-sensitive Chinese hamster ovary cells. J. Biol. Chem. 264:34163420.

18. Gould, G. W., V. Derechin, D. E. James, K. Tordjman, S. Ahern, E. M. Gibbs, G. E. Leinhard, and M. Mueckler. 1989. Insulinstimulated translocation of the HepG2/erythrocyte-type glucose transporter expressed in 3T3-L1 adipocytes. J. Biol. Chem. 264:2180-2184.

19. Oka, Y., T. Asano, Y. Shibaski, M. Kasuga, Y. Kanazawa, and F. Takaku. 1988. Studies with antipeptide antibody suggest the presence of at least two types of glucose transporter in rat brain and adipocyte. J. Biol. Chem. 263:13432-13439.

20. Kahn, B. B., and S. W. Cushman. 1987. Mechanism for markedly hyperresponsive insulin-stimulated glucose transport activity in adipose cells from insulin-treated streptozotocin diabetic rats: evidence for increased glucose transporter intrinsic activity. J. Biol. Chem. 262:5118-5124.

21. Karnieli, E., M. Armoni, P. Cohen, Y. Kanter, and R. Rafaeloff. 1987. Reversal of insulin resistance in diabetic rat adipocytes by insulin therapy: restoration of pool of glucose transporter and enhancement of glucose transporter activity. Diabetes. 36:925-931.

22. Wardzala, L. J., S. W. Cushman, and L. B. Salans. 1978. Mechanism of insulin action on glucose transport in the isolated rat adipose cell. J. Biol. Chem. 253:8002-8005.

23. Wang, C. 1987. The D-glucose transporter is tissue-specific: skeletal muscle and adipose tissue have a unique form of glucose transporter. J. Biol. Chem. 262:15689-15695.

24. Rodbell, M. 1964. Metabolism of isolated fat cells. I. Effects of hormones on glucose metabolism and lipolysis. J. Biol. Chem. 239:375-380.

25. Cushman, S. W. 1970. Structure-function relationship in the adipose cell. I. Ultrastructure of the isolated adipose cell. J. Cell Biol. 46:326-341.

26. Hirsch, J., and E. Gallian. 1968. Methods for determination of adipose cell size in man and animals. J. Lipid Res. 9:110-119.

27. Cushman, S. W., and L. B. Salans. 1978. Determination of adipose cell size and number in suspensions of isolated rat and human adipose cells. J. Lipid Res. 19:269-273.
28. Karnieli, E., M. J. Zarnowski, P. J. Hissin, I. A. Simpson, L. B. Salans, and S. W. Cushman. 1981. Insulin-stimulated translocation of glucose transport systems in the rat adipose cell: time course, reversal, insulin concentration-dependency and relationship to glucose transport activity. J. Biol. Chem. 256:4772-4777.

29. Foley, J. E., S. W. Cushman, and L. B. Salans. 1978. Glucose transport in isolated rat adipocytes with measurements of $L$-arabinose uptake. Am. J. Physiol. 234:E112-E119.

30. Chirgwin, J. M., A. W. Przbyla, R. J. MacDonald, and W. J. Rutter. 1979. Isolation of biologically active ribonucleic acid from sources enriched in ribonuclease. Biochemistry. 18:5294-5299.

31. Maniatis, T., E. F. Frisch, and J. Sambrook. 1982. Molecular Cloning: A Laboratory Manual. Cold Spring Harbor Laboratory, Cold Spring Harbor. 202-203.

32. Spiegelman, B. M., and S. R. Farmer. 1982. Decreases in tubulin and actin gene expression prior to morphological differentiation of 3T3 adipocytes. Cell. 29:53-60.

33. Feinberg, A. P., and B. Vogelstein. 1983. A technique for radiolabeling DNA restriction endonuclease fragments to high specific activity. Anal. Biochem. 132:6-13.

34. Feinberg, A. P., and B. Vogelstein. 1984. A technique for radiolabeling DNA restriction endonuclease fragments to high specific activity. Addendum. Anal. Biochem. 137:266-267.

35. Simpson, I. A., D. R. Yver, P. J. Hissin, L. J. Wardzala, E. Karnieli, L. B. Salans, and S. W. Cushman. 1983. Insulin-stimulated translocation of glucose transporters in the isolated rat adipose cell: characterization of subcellular fractions. Biochim. Biophys. Acta. 763:393-407.

36. Bradford, M. M. 1976. A rapid and sensitive method for the quantitation of microgram quantities of protein, utilizing the principle of protein-dye binding. Anal. Biochem. 72:248-254.

37. Simpson, I. A., and O. Sonne. 1982. A simple, rapid and sensitive method for measuring protein concentration in subcellular membrane fractions prepared by sucrose density centrifugation. Anal. Biochem. 119:424-427.

38. Laemmli, U. K. 1970. Cleavage of structural proteins during the assembly of the head of bacteriophage T4. Nature (Lond.). 227:680-685.

39. Wheeler, T. J., I. A. Simpson, D. C. Sogin, P. C. Hinkle, and S. W. Cushman. 1982. Detection of the rat adipose cell glucose transporter with antibody against the human red cell glucose transporter. Biochem. Biophys. Res. Commun. 105:89-95.

40. Lienhard, G. E., H. K. Kin, K. J. Ransome, and J. C. Gorga. 1982. Immunological identification of an insulin-responsive glucose transporter. Biochem. Biophys. Res. Commun. 105:1150-1156.

41. James, D. E., R. Brown, J. Navarro, and P. F. Pilch. 1988. Insulin-regulatable tissues express a unique insulin-sensitive glucose transport protein. Nature (Lond.). 333:183-185.

42. Haspel, H. C., M. Rosenfeld, and O. M. Rosen. 1988. Characterization of antisera to a synthetic carboxyl-terminal peptide of the glucose transporter protein. J. Biol. Chem. 263:398-403.

43. Iynedjian, P. B., A. Gjinovci, and A. E. Renold. Molecular cloning of glucokinase cDNA: developmental and dietary regulation of glucokinase mRNA in liver. 1987. J. Biol. Chem. 262:6032-6038.

44. Vaulont, S., A. Munnich, J. F. Decaux, and A. Kahn. 1986. Transcriptional and post-transcriptional regulation of L-type pyruvate kinase gene expression in rat liver. J. Biol. Chem. 261:7621-7625.

45. Granner, D. K., and T. L. Andreone. 1985. Insulin modulation of gene expression. Diabetes Metab. Rev. 1:139-170.

46. Alexander, M., G. Curtis, J. Avruch, and H. M. Goodman. 1985. Insulin regulation of protein biosynthesis in differentiated 3T3 adipocytes: regulation of glyceraldehyde-3-phosphate dehydrogenase. J. Biol. Chem. 260:11978-11985. 